\title{
Recent Developments of Swiss Federalism
}

\author{
Thomas Fleiner \\ University of Fribourg
}

\begin{abstract}
Since the year 2000, Switzerland has had a totally revised constitution. The main changes deal with issues of federalism. Globalization has and will have strong centralizing effects, although localization might trigger emotional and nationalistic reactions within the different ethnic communities of Switzerland. The growing mobility of people and the important percentage of foreigners living in Switzerland (20 percent) are additional challenges to the already existing but constitutionally provided diversity. This article explains the new constitution within this framework of the modern world. In particular, it focuses on the specificity of Swiss diversity and the new balance between self-rule and shared rule.
\end{abstract}

Switzerland is a small country of 7 million inhabitants surrounded by Germany, France, Italy, Austria, and the principality of Liechtenstein. Although the first development of small local state units seeking independence from foreign kingdoms dates back to the twelfth century, modern Switzerland was constituted out of 25 sovereign cantons (including six half-cantons) with the first Federal Constitution of 1848.' The twentysixth canton (Jura) was constituted more recently by separation from the Canton of Berne at the end of the 1970s. Seventeen cantons are Germanspeaking, ${ }^{2}$ four cantons are French-speaking, ${ }^{3}$ one canton is Italianspeaking, ${ }^{4}$ three cantons are bilingual (German and French) ${ }^{5}$ and one canton has three languages (German, Romansh, and Italian) ${ }^{6}$ In 1874, there was a general constitutional revision approved by the majority of the voters and the majority of the cantons adopting a new constitution. This

AUTHOR'S NOTE: This article was transformed and adapted by Thomas Fleiner for an international audience from a joint paper of Thomas Fleiner and Alexander Misic, "Föderalismus als Ordnungsprinzip der Verfassung," Verfassungsrecht der Schweiz, eds. Jean-François Aubert, Jörg Paul Mūller, and Daniel Thürer (Zürich: Schulthess, 2001). The author wishes to thank Ronald L. Watts for English editorial assistance. 'Zurich, Berne, Lucerne, Uri, Schwyz, Obwald and Nidwald, Clarus, Zug, Fribourg, Solothurn, BasleTown and Basle-Country, Schaffhausen, Appenzell Outer-Rhodes and Appenzell Inner-Rhodes, St. Gall, Grisons, Argovia, Thurgovia, Ticino, Vaud, Valais, Neuchâtel, Geneva. Half cantons are: Obwald and Nidwald, Basle-Town and Basle-Country, Appenzell Outer-Rhodes and Appenzell Inner-Rhodes. Concerning the cantons and the special status of the half cantons see Andreas Auer, Giorgio Malinverni and Michel Hottelier, Droit constitutionnel suisse, vol. I: L'Etat (Berne: Stāmpfli, 2000), p. 452; Tobias Jaag

"Die Rechtsstellung der Kantone in der Bundesverfassung," Verfassungsrecht der Schweiz, eds. Jean-François Aubert, Jörg Paul Mūller, and Daniel Thürer (Zurich: Schulthess, 2001), pp. 474-475; Ulrich Hăfelin and Walter Haller, Schweizerisches Bundesstaatsrecht, 5th ed. (Zurich: Schulthess, 2001), pp. 269-276; René Rhinow, Die Bundesverfassung 2000 (Basle/Geneva/Munich: Helbing \& Lichtenhahn, 2000), p. 69. See also Thomas Fleiner, "Switzerland: Constitution of the Federal State and the Cantons," Federalism and Multiethnic States. The Case of Switzerland, 2nd ed., eds. Lidija Basta Fleiner and Thomas Fleiner (Basel/Geneva/Munich: Helbing \& Lichtenhahn, 2000), p. 103.

"Zurich, Lucerne, Uri, Schwyz, Obwald and Nidwald, Glarus, Zug, Solothurn, Basle-Town and BaslCountry, Schaffhausen, Appenzell Outer-Rhodes and Inner-Rhodes, St. Gall, Argovia, and Thurgau.

'Vaud, Neuchâtel, Geneva, and Jura.

Ticino.

'Berne, Fribourg, and Valais.

${ }^{6}$ Crisons.

(1) Publius: The Journal of Federalism 32:2 (Spring 2002) 
constitution remained in force until 1999, although it was modified by approximately 140 amendments.

A new Constitution was introduced on 1 January 2000. The new federal Constitution did not radically change the political system, but with regard to federalism, it includes important new provisions, which may be the beginning of new federal developments in Switzerland. This article deals with this new Constitution. The Constitution was drafted after several failures to modify the old Constitution more radically. Thus, the aim of the founders of the new Constitution was to modernize the old Constitution without making major changes in the system.

Currently, Switzerland faces three important challenges: globalization and European integration, privatization and growing public debts on all levels, and migration. Twenty percent of the people living in Switzerland are foreigners. Switzerland has by far the highest percentage of foreigners per capita and the highest percentage of asylum seekers compared to all other European countries. All these challenges will have important effects on Swiss federalism. A major question is whether the new Constitution will empower Switzerland to face those challenges with flexible, innovative, and federalist policies.

\section{FEDERALISM AS A PRE-CONSTITUTIONAL PRINCIPLE}

\section{Diversity}

Swiss federalism has developed out of several different, independent, and very diverse communities, which had been structured as rural corporations, small democracies, or aristocratic or economic oligarchies. These small corporations loosened their ties and finally seceded from their big neighboring empires, kingdoms, or nations. Thus, they were not integrated into the nation-building process of Europe in the eighteenth and nineteenth centuries. On the contrary, they formed their own governmental system and constituted a state composed of different sovereign cantons, that is, of very diverse political units, different language communities, and different religions. The main purpose of the alliance (Bund), which later developed into a federal state, was to rule the political affairs of the cantons and of the alliance independently and according to their own values of democracy.

This policy was the reason that at the edge of the three big language groups of Western Europe (German, French, and Italian), some 25 democratic corporations could unite in an alliance around the Alps. In 1848, this alliance was transformed after a short civil war (Sonderbundskrieg) in 1847 into a federal state with a federal constitution. The federation is still called the Swiss Confederation for several reasons-in particular, because the German name (Schweizerische Eidgenossenschaft) cannot be translated into 
French and Italian. The very legitimacy of this unit is based on the constitutional autonomy of the cantons (self-rule) and on their constitutionmaking power at the federal level (shared-rule). The Swiss Confederation exists through and by the will of the cantons.

Each of the cantonal democratic communities could thus live and develop according to its own culture, history, language, and religion. Each canton acknowledged the legal culture of its neighbors but established its own perception of the state, law, democracy, and even state-church relations. They retained their own perception of a cantonal nationhood and state legitimacy. In turn, they maintained their own cantonal and even municipal citizenship. Thus, to the present day, every Swiss has a three-fold citizenship: municipal, cantonal, and federal (Art. 37, par. 1).

The alliance and later the federal state maintained their independence in relation to their big and powerful European neighbors. They did this to protect their own interests and to build up their joint nationhood. Nevertheless, the cantons and, in particular, those at the borders of Switzerland did maintain their cultural relationship toward their big neighbors. Thus, the Swiss citizens had, and still have, a double loyalty. Politically, they are loyal to their own state; culturally, they feel a connection to the culture of the relevant big neighboring nation.

The cantons and the Swiss Federation have thus adapted in a very diverse manner to modern constitutionalism, while also maintaining their corporativism in a rural environment and culture. ${ }^{7}$ According to the Swiss Constitution's preamble, they did not adopt the melting-pot solution of "We the people of..." (cf., the United States Constitution). On the contrary, they decided to remain a composed nation and adopted in Article 1 of the 1874 Constitution the following formula:

Together, the peoples of the 23 sovereign Cantons of Switzerland united by the present alliance, namely: Zurich, Bern, Lucerne,... and Jura, form the Swiss Confederation.

Up to the end of the nineteenth century, the causes of conflict in Switzerland were much more religious, between Protestants ( 55 percent) and Catholics (44 percent), than cultural between the different language groups. This changed radically in the twentieth century. Today, religion as a cause of conflict is fading away. Much more important is the language issue. Democratic decisions of the people by referendum show, for instance,

${ }^{7}$ See Karl W. Deutsch, Die Schweiz als ein paradigmatischer Fall politischer Integration (Berne: P. Haupt, 1976), p. 21. For a concise historical analysis, see Alfred Kölz, "Geschichtliche Grundlagen," Verfassungsrech der Schweiz, eds. Aubert, Müller, and Thürer, pp. 111-127. For diversity as fundamental value see also Thomas Fleiner, "Legal Instruments and Procedures to Prevent and Solve Ethnic Conflicts," Federalism and Multiethnic Slates, eds. Basta Fleiner and Fleiner, p.156; Rhinow, Die Bundesverfassung 2000, p. 70 and Rainer J. Schweizer, "Homogenităt und Vielfalt im schweizerischen Staatsrecht," Verfassungsrecht der Schweiz, eds. Aubert, Müller, and Thürer, pp. 161-163. For communal civism as the "essence of Swiss polity" see Lidija Basta Fleiner, "Minority and Legitimacy of a Federal State: An Outsider Perception of the Swiss Model," Federalism and Multiethnic States, eds. Basta Fleiner and Fleiner, p. 77. 
that language groups have very different opinions on foreign policy, European integration, social security, and the environment. If in the next few years the gap between the language communities becomes larger and deeper, one can foresee important conflicts between the different communities.

Taking into account these emerging new tensions among different linguistic communities, the new Swiss Constitution emphasizes the obligation of the federation to enhance peace and understanding among the different linguistic communities. As did the previous constitution, the new Constitution declares all four languages, namely, German (63.7 percent), French (19.2 percent), Italian (7.6 percent), and Romansh ( 0.6 percent) as official languages of the country (Art. 4). The three main languages (German, French, and Italian) are on equal footing. In the case of the Romansh language, Article 70 of the Swiss Constitution provides only the guarantee for the Romansh-speaking citizens to have their official contact with the federal administration in their own language.

With regard to the other three official languages, they are legally respected with a constitutionally guaranteed equal value, which has far-reaching practical consequences. ${ }^{8}$ For instance, all official decisions, in particular all legislation (bills, statutes, and ordinances), must be translated into the three languages. Bills, statutes, ordinances, and the like are only valid if they are published at the same time in the three official languages. Each text and wording has equal value with regard to interpretation. No language has priority; every language has the same original priority. In case of conflict, a judge has to decide according to the most reasonable interpretation, not according to the language in which the statute has been drafted.

The principle of freedom of language is very controversial. ${ }^{9}$ Two main principles conflict. Those who advocate the protection of minority languages feel threatened by the majority. They try to defend their language territory by invoking the collective right of the language group within its own territory to impose the language of the territory. This conflicts with the principle of an individual right to language. In fact, the new Constitution provides a compromise on this issue. Article 18 guarantees freedom of language as one of the fundamental individual liberties. At the same time, Article 70 , par. 2, stipulates that every canton shall designate its official language. In doing so, the cantons shall, in order to preserve harmony between linguistic communities, "respect the traditional territorial distribution of languages and take into account the indigenous linguistic minorities." In a conflict

${ }^{8}$ See Fleiner, "Legal Instruments and Procedures to Prevent and Solve Ethnic Conflicts," p. 126; Marco Borghi, “Langues nationales et langues officielles," Verfassungsrecht der Schweiz, eds. Aubert, Müller, and Thürer, pp. 593-606; Auer, Malinverni, and Hottelier, Droit constitutionnel suisse, p. 28; Rhinow, Die Bundesverfassung 2000, p. 71 .

${ }^{9}$ See Marco Borghi, "La liberté de la langue et ses limites," Verfassungsrecht der Schweiz, eds. Aubert, Mūller, and Thürer, pp. 607-618. The problem of languages of education is broadly discussed in Thomas Fleiner, Peter H. Nelde, and Joseph-G. Turi, eds., Law and Language(s) of Education (Basle/Geneva/Munich: Helbing \& Lichtenhahn, 2001). 
between the individual right for language and the collective right of the community to defend its language territory, the collective right wins, if it is for the sake of harmony and peace.

Peace among language groups is also referred to in Art. 70, par. 3, which requires the federal and cantonal authorities to "encourage mutual understanding and exchange between the linguistic communities."

Multiculturalism, diversity, and complexity have often been shaped out of brutal religious wars and ideological controversies that in the past risked breaking the country into pieces. Switzerland thus remains a composed nation with an important potential for conflicts. However, there is today, certainly, a large consensus that minority interests should not be pursued with violence but rather by peaceful political means. What are the reasons that make all the different communities renounce violence and accept peaceful decision-making processes? The basic reason is to be found in the legitimacy of the unity of the nation. But as the nation is not ethnically homogeneous, the only factor that does unify the country is a shared commitment to the same political values and the internalized acceptance of the rules of the game of a corporate local and federal consensus democracy. Such a general acceptance, however, cannot be based solely on specific principles of shared rule; it depends just as much on the self-rule principle, that is, on the autonomy of cantons and municipalities.

The characteristics of the new Constitution will in fact put more emphasis on the principle of shared rule than on the principle of self-rule as expressed by the autonomy of the cantons. It provides in particular more possibilities for cantonal governments to participate in executive decisions on the federal level (Art. 45, Art. 55, the Statute on the Participation of Cantonal Governments on the decision-making process in international affairs and the growing power of the Conference of the Presidents of Cantonal Executives).

The most provoking challenge of Swiss federalism is its multiculturalism. This multiculturalism is not the outcome of immigration as in such federal countries as the United States, Canada, and Australia. Multiculturalism has its roots in the ancient history of communities that have always lived in Switzerland. The as yet not fully solved challenge in immigration countries with regard to their indigenous populations is more comparable to the multiculturalism that European countries such as Switzerland have to cope with. The major and most challenging question thus is: how can so diverse a society as the Swiss community, which is not homogeneous like Germany, find its unity and legitimacy in common political values? How can the exclusive political values of local democracy and federalism, which are not universal and inclusive, enable a composed people to be united within a European environment, which today bases political unity on universal values such as democracy, the rule of law, and human rights? 
This challenge becomes even more worrying in our times. ${ }^{10}$ Both European integration and globalization trigger emotional counter-reactions in the form of nationalism and ethnic conflicts in local areas. Financial constraints for local authorities require centralization by either "supracantonal" cooperation or mergers of cantons or municipalities. The emotions of the citizens, on the other hand, lead to pressures for more autonomy and, in some cases, even secession. The question, then, is whether the Swiss, belonging to their different cultures, will be able in a future united Europe or united world to identify themselves as a people united by the same political beliefs and political culture.

The state of modern times has derived its legitimacy either as a state created by the nation or from a pre-constitutional ethnically homogeneous people." In the former, the "nation" has been "constituted" by the state, that is, by the citizens (citoyens) of the state territory accepting the universal values promoted by the constitution (e.g., the French case). In the latter, the state can be created-as in the German case-by an ethnically homogeneous people. According to this latter understanding, the ethnically homogeneous people are united by nature, that is, by common history, tradition, culture, language, or religion. This unity by nature "produces" the right of self-determination. The preamble of the German constitution thus stipulates: "the German People have adopted, by virtue of their constituent power, this Constitution." Between these two poles of its neighbor countries, France and Germany, Switzerland was able to establish its own concept of a composed nation based on a social compact to establish cantonal authority and a federal alliance to establish federal authority. ${ }^{12}$

Although the Swiss Constitution of 1874 explicitly stated that the people of the different sovereign cantons form the federation, the new Constitution does base its legitimacy on both the Swiss nation and on the peoples of the cantons. ${ }^{13}$ Here the question remains as to whether the people of Switzerland is a unity and, if so, what is the basis of this unity? It can well be that the traditional political procedures and institutions, such as direct democracy, federalism, and autonomy of local authorities, have been so strongly internalized that they have turned a culturally diverse population into a politically homogeneous people. It may well be that federalism, which has combined the shared power of the different cultures with the strong autonomy of cantons and municipalities, has been and still is the most

${ }^{10}$ See Peter Pernthaler, "Die Globalisierung als Herausforderung an eine moderne Staatslehre," in: FS KojA, (Vienna, 1998), p. 85; Daniel Thürer, "Recht der internationalen Gemeinschaft und Wandel der Staatlichkeit," Verfassungsrecht der Schweiz, eds. Aubert, Müller, and Thürer, pp. 37-61.

"See Thomas Fleiner and Lidija Basta Fleiner, "Federalism, Federal States and Decentralization," Federalism and Multiethnic States, eds. Basta Fleiner and Fleiner, p. 8.

${ }^{12}$ See Basta Fleiner, "Minority and Legitimacy of a Federal State: An Outsider Perception of the Swiss Model," p. 77.

${ }^{13}$ Rhinow, Die Bundesverfassung 2000, p. 68; Anton Greber, "Die strukturellen Grundlagen des schweizerischen Bundesstaats," Constitution 2000, eds. Thomas Fleiner et al. (Basle/Geneva/Munich: Helbing \& Lichtenhahn, 2000), p. 7. 
important integrative factor in the reality of the Swiss population. It is certainly thanks to these common political values that Switzerland up to now has not been split up into separate language and/or religious communities.

Thus, the legitimacy of the Swiss Confederation is based on the peoples of the cantons as well as on a "Swiss nation" composed of different cultures and religions. This nation is fragmented by the cantons, which represent the political units of the federation. The peoples in the cantons are politically committed to their respective cantons and to the federation, but culturally they are also linked to the strong culture of the related people in their respective neighbor countries. The unity of the state thus is based on the common understanding and on the common perception of these fundamentals of Swiss politics. This historical reality ultimately shapes the federal structure of the federation. If the Constitution did not take this reality into account, the Confederation would ultimately split into the different ethnic communities. ${ }^{14}$

It is this reality of the fragmented Swiss society that induced the drafters of the new Constitution to provide in the preamble a clear mandate for the Confederation to be "determined to live our diversity in unity respecting one another." Article 2, par. 2, of the Constitution obliges the Confederation to foster the cultural diversity of the federation. Such a provision is unique compared with other constitutions. The United States Constitution is based on the melting pot concept in referring to "We, the people of the United States." The South African Constitution also stipulates unity by diversity, but taking into account the wounds of history, it professes to heal the divisions of the past.

The paradoxical formula of "diversity in unity" (preamble) describes the federal principle according to the Swiss understanding of its multicultural reality. Diversity in unity is the starting point of different theories on federalism. ${ }^{15}$ It not only emphasizes that different cultural communities can be united by their firm will to be a political union, but it expresses also the dialectic tension between self-rule, shared rule, and solidarity. Federalism as a structural principle depends on the constitutionally established and protected balance between self-rule and shared rule. ${ }^{16}$ All measures of the federal government and, in particular, federal statutes have to respect this balance in order to accomplish the mandates of the constitution.

The constitutional powers of the federal and cantonal authorities are separated and divided according to the federal Constitution (Article 3). In

${ }^{14}$ Peter Saladin, "Commentary ad Article 3 (Constitution 1874)," Kommentar zur Bundesverfassung der Schweizerischen Eidgenossenschaft vom 29. Mai 1874, eds. Jean-François Aubert et al. (Basle/Zurich/Berne: Helbing \& Lichtenhahn/Stāmpfli/Schulthess, 1987-1996), pp. 6-7.

${ }^{15}$ See Thomas Stauffer and Nicole Töpperwien, "Balancing Self-Rule and Shared Rule," Federalism and Multiethnic States, eds. Basta Fleiner and Fleiner, p. 41; Anton Greber, "Die vorpositiven Grundlagen des Bundesstaates" (diss., Fribourg University, 1999).

${ }^{16}$ Daniel J. Elazar, Exploring Federalism (Tuscaloosa: University of Alabama Press, 1987), p. 5. 
practice, they are redefined in a complex network, which can only function in a spirit of comity and federal-cantonal partnership. Swiss federalism thus is not simply a complementary instrument for an additional separation of powers in order to limit state powers by vertical checks and balances. ${ }^{17}$ The multicultural diversity of Swiss society is the pre-constitutional reality reflected in Swiss federalism. Thus, federalism is the fundamental principle underling the legitimacy of the Constitution. ${ }^{18}$

\section{PEACE AND LIBERTY}

Balance Between Individual and Collective Rights. The primary aim of the modern liberal state is individual liberty, that is, the protection and promotion of fundamental rights and values. A multicultural state such as Switzerland, which is confronted with a high potential for internal conflicts, has not only to be concerned about individual liberty but also to safeguard peace and harmony among the different communities. In fact, it has to manage and enhance peace not only between individuals, but just as much between the different communities. One of the most important aims of Swiss federalism, thus, is to guarantee, apart from individual liberty, the multiculturalism of its diverse communities.

In order to respond to these necessities, the federal Constitution has established political institutions and procedures that facilitate peaceful settlements or management of internal conflicts. In this sense, the preamble to the new Constitution explicitly resolves to "strengthen liberty, democracy, independence and peace (not only international) in solidarity and in openness to the world." Thus, not only liberty but also peace among the cultural communities are among the declared aims of the Constitution. In fact, during Swiss history, individual liberty has often been restricted for the sake of peace among the cultural and linguistic communities. Religious and language communities have always claimed their rights under the title of collective rights, which in certain cases restrict individual liberties whenever they felt threatened by other more numerous or more powerful communities.

Liberty of Religion and Peace among Religious Communities. With regard to the liberty of religion (Article 15), the federal Court has not only taken into account individual freedom as a fundamental right, it has respected just as much religious peace as a main purpose of the federation. The Court, therefore, has based its decisions not explicitly but implicitly on the collective right of religious communities to pursue among the communities within their traditional territories the interest of the majority religion. ${ }^{19}$

${ }^{17}$ See Hansjōrg Seiler, Gewaltenteilung (Berne: Stāmpfli, 1994), p. 130.

"Walter Kăgi, "Die Grundordnung unseres Kleinstaates und ihre Herausforderung in der rweiten Hälfte des 20. Jahrhunderts," Festschrift Schweizerischer Juristenverein (Basle, 1964), p. 16; Philippe Mastronardi, "Strukturprinzipien der Bundesverfassung?" Beihefle zur Zeitschrift für Schweizerisches Recht (ZSR) 7 (Basle) Frankfurt a. M., 1988), pp. 28, 37. The federal principle is, however, endangered. See Hãfelin and Haller, Schweizerisches Bundesstaatsrecht, p. 54.

${ }^{19}$ See Jōrg Paul Mūller, Grundrechte in der Schweiz, 3rd ed. (Berne: Stāmpfli, 1999), p. 80. 
Today, religion as a potential cause of conflict in Switzerland is fading away. Nonetheless, Article 72, par. 2 empowers the federal and cantonal authorities explicitly to take necessary measures to maintain public peace among the different religious communities.

Liberty of Language and Principle of Territoriality. Although the peril of religious conflict no longer looms in Switzerland, religious and language conflicts have risen all over the globe and turned into the most dangerous conflicts threatening world peace. However, the tensions among language groups have remained in Switzerland. Such tensions have even increased during recent decades. Consequently, the new Constitution (Article 70) confers the explicit burden and responsibility on the federal and cantonal authorities to seek harmony among the different language communities. This is a particular burden for bilingual or even multilingual cantons. Three cantons are bilingual (French/German: Valais, Fribourg, and Bern), and one canton is trilingual (German, Italian, Romansh: Grison/Graubünden). The canton of the Tessin is only Italian-speaking, but it has a small Germanspeaking municipality (Bosco Gurin). Harmony and peace between language communities is not only an issue between cantons, it is also an issue of intracantonal harmony in these cases.

The contradictory wording of the Constitution between the individual right to language (Article 18) and the collective right of minority territories to protect their language (Article 70) has already been mentioned. They will need a quite innovative interpretation by the federal Court. ${ }^{20}$

Constitutional Procedure for the Solution of Territorial Conflicts. The Constitution of 1848 was been drafted in the aftermath of the civil war in 1847 between the Roman Catholic conservative cantons and the Protestant liberal cantons. The Catholics were linked to the Catholic monarchies. The Protestant liberal cantons were under the influence of the French Revolution and were promoting a liberal constitution reflecting the universal values of the declaration of human rights. The Catholic cantons established a specific alliance (Sonderbund) in order either to defeat the liberal Protestants or to secede from a liberal democratic Switzerland. The Catholics wanted to restore Switzerland to the ancient aristocratic times of the eighteenth century. The liberals wanted to constitute a new modern unitary state incorporating governmental branches with separated and limited powers in order to protect individual rights. In the so-called war of the Sonderbund, the Catholics were defeated and the liberals were able to establish a constitution according to their conception of Switzerland.

However, the sense of compromise established through preceding centuries of conflicts and confederal relationships and the desire for partnership prevailed. It enabled the founding fathers of the new federal state to respect the interests of the conservatives by providing strong cantonal

${ }^{20}$ Jbid., 140. 
autonomy and a role in shared rule based on the concept of the equal sovereign rights of the cantons. This respect for the equal sovereign rights of the cantons as federal units did have and still has far-reaching consequences because the size in population and territory of the cantons is very different. The "asymmetry" between the large and the small cantons is unusually big. This has as the effect, for instance, that in a constitutional referendum, the vote of a citizen of the half-canton of Appenzell (which counts only as a half-cantonal vote) has a value 37 times higher than the vote of a citizen of the most populated canton, Zurich.

The conservative cantons for their part accepted some liberal constitutional rights and the prohibition of any political alliance among particular groups of cantons. As certain borderlines between some cantons have often been disputed, with the risk of open conflict, the constitutions of 1848 and 1874, in the interests of intercantonal peace, considered the territories of the cantons as "sacred," and thus did not foresee any territorial change among the cantons. On the contrary, for the sake of peace among the cantons, the Constitution obliged the federal authorities to protect and to guarantee the territories of the cantons.

Nevertheless, the most important dispute on territory to arise subsequently, that concerning the Jura region of the Canton of Berne, could not be settled by such an explicit lack of regulation. The rigorous freezing of cantonal territories could not provide a final solution. This policy did not prevent the people of the French-speaking part of the Canton of Berne living in its northern part, which was the historic region of the Jura, from seeking secession from the German-speaking Canton of Berne. The dispute lasted for more than a century.

Finally, without any specific provision in the federal Constitution, the Canton of Berne decided, empowered by its own residual power, to grant the right of self-determination to the people living in the Jura area. However, while this right was provided for the region as a whole, at the same time the right of self-determination was given to every district and, in certain cases, even to the municipalities. If the region favored secession, the smaller districts and, in some instances, even the municipalities could decide whether they would prefer to remain in the Canton of Berne or to join the new Canton of Jura. This cascade of different referendum votes allowed both cantons to reshape the borderlines not only along the language border but also along the religious division between French-speaking Protestants and Frenchspeaking Catholics living in the Jura region of the Canton of Berne.

If the right to self-determination had been given only to the territory of the region as a whole, the conflict could not have been settled democratically. A vote based on a simple-majority principle with consequence for the entire region would have been a major cause for unsolvable conflicts. ${ }^{21}$

${ }_{21}^{21}$ For an analysis of general problems of ethnic conflicts and the experiences of the Swiss Constitution, see Fleiner, "Legal Instruments and Procedures to Prevent and Solve Ethnic Conflicts," p. 145. 
Thus, the pragmatic (although sometimes very painful) procedure of the secession of the Canton of Jura from Berne respected the following principles: ${ }^{22}$

1. All parties accepted a procedure based on a common consensus. The idea of a unilateral secession was never realistically invoked. The final decision of a new canton required first, the constitutional amendment of the Canton of Berne accepted in a popular referendum, second, a vote of the people living in the area of the Jura region, third, the acceptance of the districts, fourth, the decisions of the municipalities, and fifth, the agreement of the majority of the Swiss cantons and the people of Switzerland to integrate the Canton of Jura as a new federal and constitutional unit within the Confederation.

2. Decisions did not follow the simple-majority principle ("the winner takes all"). They took into account even majorities of small municipalities, which were de facto granted the status of a state unit, as they had the power to decide which canton they wanted to belong to.

3. It was considered to be part of the constitutional autonomy of the Canton of Berne to provide in its own cantonal constitution a democratic procedure that could implement a peaceful settlement of the right to self-determination for a region within the territorial sovereignty of the canton.

4. The entire procedure was influenced by the necessity that in such crucial decisions, even small minorities belonging to a municipality must be part of the consensus-making process.

Based on this democratic procedure, Switzerland finally amended its federal Constitution by providing that the Canton of Jura should in 1979 be constituted as a canton within the Confederation and that it would be the twenty-sixth constituent canton of the Confederation (Article 1 in fine).

This democratic and finally peaceful secession procedure was the model for a new provision in the new Constitution regarding territorial changes. ${ }^{23}$ Article 53 provides that any modification of the number of the cantons or of their status is subject to the assent of the population concerned, of the cantons concerned, and of the Swiss people and of the cantons at large. Thus, the new Constitution regulates the democratic procedure for secession or reunion.

In neither case can it be a unilateral decision. Secession or reunion requires the consensus first of the seceding or uniting population and,

${ }^{22}$ Basta Fleiner, "Minority and Legitimacy of a Federal State: An Outsider Perception of the Swiss Model," p. 90; Hāfelin and Haller, Schweizerisches Bundesstaatsrecht, p. 285.

${ }^{23}$ See Jaag, “Die Rechtsstellung der Kantone in der Bundesverfassung," p. 476; Hāfelin and Haller, Schweizerisches Bundesstaatsrecht, pp. 565-577. 
second, of the entire population of the country and the majority of the cantons. The procedure seems to take both minority interests and majority interests into account. One can say, then, that as of 2001, the Ethiopian Constitution $^{24}$ and the Swiss Constitution are the only constitutions in the world that explicitly regulate secession procedures.

Paragraph 3 of Article 53 even provides a procedure for changes of territory without modification of the number of the cantons. In such territorial modifications, the proposals are subject to the assent of the population concerned, of the cantons concerned, and of the federal Parliament. As there is still dispute within the Canton of Berne with regard to its Protestant French-speaking region in the Jura, which generally did not want to join the new French-speaking but Catholic canton, that region might still decide in the future according to this procedure whether it prefers to join the new Canton of Jura.

Switzerland of the nineteenth century was internally very fragile and externally under threat from neighboring monarchies. This potential instability was the reason the Constitution of 1874 prohibited groups of cantons from constituting political alliances, which could endanger the unity of Switzerland. ${ }^{25}$ The new Constitution renounces any such prohibition because there is no longer any real threat to the unity of the country. This may be a case proving that over time, democratic constitutions can very well provide institutions and procedures that integrate and strengthen the legitimacy of the state.

\section{FEDERALISM AND DEMOCRACY}

The Tyranny of the Majority. Is democracy limited by federalism; does federalism violate the democratic principle of majority rule? Does it even replace democracy by granting minorities rights they would never receive in a system based on a "winner takes all" democracy? Democracy is based on the principle of one person, one vote, one value. ${ }^{26}$ Such equal rights can only be achieved and implemented in the democracy of a unitary state. In such a centralized state, minorities have no possibility for an autonomous rule, opting out from majority decisions, or participating (shared rule) in the central decision-making process with any chance of defending their legitimate interests against the majority. Equality in the sense of completely equal rights is the main target of such a democracy, as developed out of the French Revolution and of the Westminster-model. ${ }^{27}$

${ }^{24}$ See Ahmednasir M. Abdullahi, "Article 39 of the Ethiopian Constitution on Secession and SelfDetermination: A Panacea to the Nationality Question in Africa?” Verfassungen und Recht in Übersee. Law and Politics in Africa, Asia and Latin America (Baden-Baden: Nomos, 1998), p. 440

${ }^{25}$ See art. 7 (Constitution 1874).

${ }^{26}$ See Giovanni Sartori, The Theory of Democray Revisited (Chatham, NJ: Chatham House, 1987), passim; Basta Fleiner, "Minority and Legitimacy of a Federal State: An Outsider Perception of the Swiss Model," p. 94, suggests in p. 95 that in Switzerland, "federalism has been introduced as a structural principle of democracy.

${ }^{27}$ See Alexis De Tocqueville, De la Dêmocracie en Amérique, Oeuvres complètes II (Paris: Pléiade, 1992) part II, chapter 7: “De l'omnipotence de la majorité aux Etats-Unis et de ses effets," and chapter 8, "De ce qui tempère aux Etats-Unis la tyrannie de la majorité." 
This understanding of democracy as a pure and efficient majorityproducing instrument does not correspond to the Swiss perception of democracy. In Switzerland, democracy is perceived as a tool of individual and collective self-determination and, thus, of individual and collective freedom. If self-determination cannot be achieved individually, it has to be achieved democratically within a community. In smaller communities, the chances for every participant to pursue his or her interests as much as possible are higher than in larger communities. The smaller the democratic unit, the higher are the possibilities of self-determination for each groupmember. If democracy is understood as an aim to guarantee individual and/or collective self-determination, it can only be optimized in a decentralized and federal way. Only federalism, conceived as a state organizational principle, can allow the decentralization of decision-making to small genuinely autonomous collectivities, which can also participate through the shared power principle in the decision-making process at the central level. According to the Swiss view, federalism and democracy have to be seen as complementary to ensure freedom and self-determination. Federalism, understood from this point of view, is even the necessary condition for the establishment of a consensus-driven democracy. Without federalism, democracy will erode and vice versa. Thus, the consensus-driven democracy in Switzerland is essentially linked to Swiss federalism.

Consensus-Driven Democracy. Democracy is not only a procedure to establish a legitimate government but also a procedure to ensure peaceful settlements of conflicts, in particular the conflicts of a state fragmented by different ethnic communities. It has high legitimacy based on rational arguments and pragmatic compromises among conflicting interests. The real motor for this consensus-driven democracy in Switzerland is the Swiss system of direct democracy. In the case of legislative referendums, decisions taken by the legislature are ratified by the simple majority of voters. Constitutional amendments need, in addition to the majority of the voters, majorities in a majority of the cantons.

The legislative referendum seems to exclude any consensus, as every simple majority can decide. However, reality is different. Government proposals are usually rejected in a referendum when they lack a fundamental consensus among the political elite and the big parties. Thus, the political elite is forced to seek compromises if it needs the approval of the majority of the voters. On the other side, no party has a veto power. Generally, in practice, where one party has misused its position in the process, its position has usually been rejected in the referendum.

This consensus-driven democracy is one of the basic pillars of the Swiss state based on the notion of the composed nation. The Westminster-type democracy would condemn any minority to be a permanent loser. Only in a system that has as a target of the decision-making process achieving the 
highest majority possible, not just 51 percent, do minorities have a chance not only to be protected as a folklore minority but also to get their legitimate interests accepted by the majority. Thus, a consensus-driven democracy enables legitimization of policy with regard to minorities.

Permanent losers will never identify with the state they live in. They will always feel themselves to be second-class citizens. Thus, a multicultural state can only survive if it introduces a democratic system that has as its target a consensus in which minorities participate, and not just a simple majority.

In a multicultural state, in which cultures should flourish and develop and in which they should not be assimilated and "equalized" in a melting pot, each cultural community must have the possibility to identify with the state. Such a result is only possible if those decisions that have essential and fundamental consequences for the state are supported by a large consensus, including the great bulk of the different communities.

Apart from the system of direct democracy, the principle of shared powers established by the Constitution also limits the simple-majority principle. Shared power principles are provided through the second chamber, which has been constituted like the U.S. Senate with 46 members representing the 23 full cantons in the state council: two per canton for the 20 full cantons and one for each of the six half-cantons (Article 150). Shared rule is not only implemented through the second chamber. Just as important is the power of the cantons to participate as cantons in all constitutional referendums. According to the Constitution, any constitutional amendment needs to be ratified by the majority of the voting citizens in the federation and the majority of the voters in a majority of the cantons (Article 140, par. 1 , lit. a), which, as already mentioned, differ to a large extent in size and population. An indirect effect on the shared power system in Switzerland has to be seen in the electoral system. Given that the cantons are the constituencies for the members of the first chamber, the cantonal parties decide on the candidates for election to the federal Parliament. This system, including the principle of a fixed term collegial executive, avoids too much political influence of federal (central) politics within cantonal voting (as occurs in Germany). On the contrary, it gives cantons, through their parties, an additional opportunity to influence federal policies. These constitutionally provided rules of shared power have not been changed with the new Constitution.

Enlarged Shared Power. In general terms, the new Constitution has enlarged the possibilities for shared power and diminished the scope of self-rule, that is, the autonomy of the cantons. As international cooperation, in particular integration into the European Union, will have a great impact on Swiss federalism, the new Constitution contains an increased number of provisions that take into account international cooperation. This 
cooperation is not limited to the federal government. Article 55 provides that cantons have to participate in all decision-making processes with regard to international cooperation. A specific statute already regulates the participation of the cantonal governments in matters of foreign policy.

In addition, Article 45 provides that cantons shall participate in decisionmaking at the federal level and, in particular, in legislation, where it is provided by the Constitution. This provision also obliges the federal government to inform cantons of important policies being planned by the federal government.

The new Constitution thus contains important provisions to enlarge the scope of shared power. Historically, the founding fathers of the Constitution defended the equal sovereign rights of the cantons sharing federal power on the bases of the quality of sovereignty they had conveyed to the federal government by the federal Constitution. In quantity, those sovereign rights may be different but they do not differ in quality. Thus, the Constitution implemented two principles of representation: representation of the people based on one person, one vote, and one value in the first chamber, and representation of the peoples of the cantons based on two representatives for each sovereign canton, and one representative for each sovereign half-canton.

The new provisions of the Constitution do not limit shared power to the liberal principle of the people's representation in parliament. It enlarges the shared power process to include empowering cantonal governments. Thus, generally, the new Constitution opens a new concept of federalism incorporating the executive branches of government. In the future, cantons will have the right to a role in the exercise of the shared power based on the principle of representation through their citizens as voters and through the participation of their executive branches of government.

Democracy of Municipalities. Diversity and multiculturalism are not limited or identical with the territories of the cantons but in several cases with the territories of the municipalities. Multiculturalism with regard to religion and to language is often determined by municipal boundaries. This is the very reason why federalism in Switzerland cannot be reduced to the relationship between cantons and federal government. It has to incorporate also the local democracies of the municipalities. The small democracy in the local municipal area is the fundamental element of Swiss federalism. Contrary to most nation-states, which, by the historic tradition of the monarchies, have been developed "top-down," Switzerland is one of the very few countries that has been developed "bottom-up." The municipal democracies are the units at the bottom of the state, which guarantee and foster the diversity of Switzerland. ${ }^{28}$

\footnotetext{
${ }^{2 n}$ See Hansjōrg Seiler, "Gemeinden im schweizerischen Staatsrecht," Verfassungsrecht der Schweiz, eds. Aubert, Müller, and Thūrer, pp. 491-506; Erich Bapst, "The Autonomy of Swiss Communes: A Pleading. Federalism without Autonomous Communes? Impossible!" Federalism and Multiethnic States, eds. Basta Fleiner and Fleiner, p. 213.
} 
This corporate democracy is an essential element in the perception of democracy and federalism. The Swiss citizen is a citizen of the municipality, of the canton, and of the Confederation. Each taxpayer pays taxes to the municipality, to the Canton, and to the federal government. The municipality takes care of the daily necessities of citizens, and through the system of direct democracy, it controls financial expenditures, elects local parliaments as well as the members of the executive council, decides on taxes, engages in local planning, and so on. The municipality is the arena in which selfdetermination is implemented directly. According to the Swiss understanding of federalism, the federal structure of the country has to ensure local democracy as an essential part of self-determination and conflict settlement.

According to the self-rule principle, the structure, organization, and autonomy of municipalities are subject to cantonal law. This was the reason why the autonomy of municipalities was not even mentioned in the old Constitution. The new Constitution (Article 50) provides a special section for the protection of municipalities. It guarantees their autonomy according to cantonal law and obliges the federal government to evaluate all federal measures that might have consequences for the municipalities. Economic development and, in particular, the side-effects of globalization, the complexity of the welfare state, and the principle of executive federalism particularly overburden small municipalities (less than 500 inhabitants) with tasks they cannot cope with anymore. Cantons are, therefore, confronted with the need to facilitate or even to enforce the merger of small municipalities that do not possess the necessary means in terms of their human and financial capital to fulfill their basic obligations. Such mergers of municipalities are regulated by cantonal law, which in most cases requires a referendum of the population concerned. As in any merger, at least one part of the population will lose the name and, therefore, the identity with its historic commune. Hence, citizens often prefer to pay a higher price in taxes than to give up their home community and merge with another municipality.

\section{EQUAL LIVING CONDITIONS}

Article 72, par. 2, of the German constitution provides federal legislative competence if it is necessary for the establishment of equal living conditions throughout the country. ${ }^{29}$ A similar provision is to be found in Article 130 of the Spanish Constitution, which provides that the "public authorities shall attend to the modernization and development of all economic sectors, particularly of agriculture, livestock raising, fishing, and handicrafts, in order to equalize the standard of living of all Spaniards." 
Modern constitutions generally require equal rights with regard to equal opportunities, not equal results. ${ }^{30}$ Neither equal opportunities nor equal results, however, are guaranteed according to the Swiss Constitution. Swiss federalism does not promote equality of living conditions among the cantons. Diversity and autonomy are only possible if human beings pay the price of economic discrimination among different cantons and even different municipalities. Swiss federalism has always paid this price for the sake of the fiscal autonomy of the cantons. Equalization would mean centralization, and this, it is believed, would destroy diversity. With the possible integration in the European Union, which promotes an open market based on equal opportunities, Switzerland may have to face a new stage of federalism. Thus, the federal Parliament has already put into force a law guaranteeing equal opportunities with regard to the internal market in Switzerland. This law requires quite a number of cantonal legislative modifications in order for them to give up internal cantonal discrimination. However, according to evaluations (Art. 170) of the federal Parliament, most cantons have not followed these federal obligations. This example shows how difficult it will be even within Switzerland to establish equal opportunities in reality. ${ }^{31}$

In a state with a fragmented society, solidarity is not only an issue between individuals but also between different cultural communities and religions. Thus, solidarity as a basic element holding the potential conflicting society in Switzerland together has to provide equal opportunities not only for individuals but also for communities. Equality of community may often even have priority over equality of individuals. This may be the very reason why the old constitution did not, and the new Constitution still does not, have any provision guaranteeing equal opportunities among individuals or equal living conditions for the whole population. It gives equal rights and the "right to be equal" as part of a minority community the same value.

The understanding of equal rights has accordingly two different meanings: the right to "be equal" and the right to "equal rights." If persons belonging to the Romansh minority have only equal rights, they will always be considered or will consider themselves as second-class citizens. In a totally equal society, they remain a tiny minority, which feels de facto discriminated in a state that reduces the citizen only to a political person naked of any culture. If they have, however, the right to be equal, they must be accepted on equal terms as being part of their cultural community. A Romansh-speaking citizen needs to have the same value as part of his or her community just in the same way as persons belonging to the majority of the German-speaking community. It is obvious that Switzerland is seeking a balance between equal individual rights and the right to be respected as equal although belonging to a minority.

${ }^{30}$ See Karl Hesse, Der unitarische Bundesstaat (Karlsruhe: CF Múller, 1962), and Heidrum Abromeit, Der verkappte Linheitsstaat (Opladen: Leske \& Budrich, 1992).

${ }^{31}$ Thomas Fleiner, Allgemeine Staatslehre, 2nd ed. (Berlin: Springer, 1995), p. 181 
This also has consequences with regard to inequalities of taxes among cantons and municipalities. Thus, the new Constitution provides also only a federal competence to harmonize the cantonal legislative systems of taxes and the procedure of taxing among the different cantons (Article 129, par. 2). The amount of taxes, that is, the income per year, on the other hand is decided either by a cantonal parliament or by popular cantonal referendum. As a consequence, individuals with the same income have to pay considerably different taxes depending on the municipality and canton in which they have their domicile.

Some equalization is provided (Article 135)..$^{32}$ The system of fiscal equalization has been under general discussion and will be fundamentally modified. ${ }^{33}$ It will have a basic influence on Swiss federalism. The main target is to give cantonal policy more autonomy by global grants to support intercantonal cooperation, to give economically weak cantons more federal resources, and to finance cantonal tasks, which because of their specific circumstances, are particularly costly.

\section{SWISS INSTITUTIONS AND STRUCTURE IN TERMS OF ITS “FEDERALIST PHILOSOPHY”}

Cantonal Autonomy and Self-Rule

Cantonal Sovereignty. In the European perception of law, the state is the Leviathan as set forth in to the social compact theory of Thomas Hobbes. Sovereignty is perceived as arising from a "Big Bang," out of which emerged the legal system, the state, the constitution-making power, legitimacy, and court jurisdiction. This supreme power and jurisdiction cannot be divided. Competence belongs ultimately either to the federation or to the cantons. If it belongs to the federation, the cantons cannot be states. A state without sovereignty cannot exist; states and sovereignty are indivisible. ${ }^{34}$ Those who still advocate this theory ${ }^{35}$ of absolute sovereignty cannot accept the idea of a division of sovereign powers. ${ }^{36}$ Although sovereignty is not divisible in such theory, the old and the new Swiss constitutions have claimed that the cantons are sovereign insofar as their sovereignty is not limited by the federal Constitution (Article 3). The residual power remains with the cantons, which, as sovereign units, handed over partial sovereignty to the Confederation.

${ }^{32}$ See also Article 46 par. 3; 83 par. 3; 86 par. 3 (e); 128 par. 4.

${ }^{33}$ See Hans Maeder and Kuno Schedler, eds., Perspektiven des Finanzausgleichs in der Schweiz (Bern: 1996). Franz Eng et al., eds., Neuer Finanzausgleich zwischen Bund und Kantonen: Die A uswirkung auf die Gemeinden (Bern: 1997); Markus Fuchs, Das Instrument Finanzausgleich - dargestellt unter besonderer Berücksichtigung des indirekten Finanzausgleichs zwischen dem Kanton Luzern und seinen Einwohnergemeinden (diss., Fribourg University, Luzern 1987). Links: http://wrow.efd.admin.ch/d/aktuell/nfa, 9 July 2002 , http://coc.idt.unisg.ch/ , 9 July 2002.

${ }^{34}$ Saladin, "Commentary ad Article 3 (Constitution 1874)," p. 18.

${ }^{35}$ For a thorough analysis see Max Imboden, "Die staatsrechtliche Problematik des schweizerischen Föderalismus," Staat und Recht, Ausgewähtte Schriften und Vorträge, ed. Max Imboden (Basel/Stuttgart, 1971) p. 175.

${ }^{36}$ Alexander Hamilton, Federalist Papers, Nr. 33. 
Although cantonal sovereignty is limited, cantons dispose of all the traditional state powers. They sustain all three branches of government: legislative, executive, and judicial. They also have substantial but limited constitutional powers and even a treaty-making power (Article 56). They decide on their own democratic system and determine the exercise of power in their system of direct democracy. They also decide on their own structure of internal decentralization, including the powers of local authorities. Much more important is the legitimacy of state government. This legitimacy does not depend on the federal legitimacy but on the peoples of the canton. Cantons do not derive their legitimacy from the federal government; their power structure is, and has to be, legitimized by their own people. Thus, the legitimacy of the federal and cantonal powers in Switzerland depends on different constituencies. The people, who are sovereign (Article 148, par. 1), give legitimacy to the state power. In Switzerland, depending on its factual diversity, the constituencies, which provide legitimacy, are divided by the federal and cantonal sovereigns. ${ }^{37}$

Are Cantons "States?" This question is related to the European understanding of the "state" as a collective unit conceived as the fountain of justice and law. It is related to the European theory of the state, which was developed in parallel to the building of the European nation-states in the nineteenth century. The question of whether cantons have to be considered as states has concrete consequences with regard to international law. International law still considers states as units and as only subject to international law. However, in strongly decentralized federal states, the constitutional units of the federation may also participate in international decisions and specially in international treaty-making. International law neglects this fact and denies to constitutional units of federal states a role as parties before international courts. Thus, if Switzerland were to join the European Union, cantons could never sue or be sued before the European Court, although there might be cases in which the responsibility to apply European law lies with the cantons and not with the federation.

As states, the cantons adopt their own constitutions. They have the limited but still undisputed constitution-making power. The preamble to the Constitution of the Canton of Jura, for instance, invokes the French Declaration of Human Rights, the Universal Declaration of Human Rights, and the European Convention on Human Rights. The powers of the governmental branches are not derived from the federal Constitution or federal law; they depend for their legitimacy on the people of the canton. If federalism is a response to multiculturalism, the cantons as the basic holders of cultural communities have a legitimacy that is not derived from any other unit than from their own people, the very constituency of the canton.

${ }^{37}$ See also Saladin, “Commentary ad Article 3 (Constitution 1874)," pp. 19-20 
Autonomy and Division of Powers. According to Article 3 of the Constitution, ${ }^{38}$ all the powers of the federal government have to be spelled out in the federal Constitution. As the cantons have the residual and original power, their competencies are not comprehensively articulated in the federal Constitution. According to several cantonal constitutions, the residual power has even remained at the municipal level. According to the federal Constitution of 1874, the federal government could only claim competencies by interpreting the relevant articles of the Constitution. This has changed somewhat with the new Constitution. According to Article 42, par. 2, the Confederation shall assume tasks that require uniform regulation. This article could be given a very broad interpretation. If this were to be the case, the federal legislature would in effect decide which competencies are needed for necessary uniform regulations. All these articles were originally drafted with the idea that the new Constitution would, contrary to the old Constitution, provide a constitutional review of all statutes. This "revolutionary" proposal did not get the approval of Parliament, however. Thus, it will only be in the jurisdiction of the federal legislature to decide to what extent Article 42, par. 2, can be used for federal competencies without explicit constitutional provision. The question arises, will it have the same centralizing impact in the future as the commerce clause of the U.S. Constitution?

With regard to the actual distribution of powers between the Confederation and the cantons, the new Constitution does not contain any important changes. One of the main aims of the new Constitution was to give the actual system a modernized wording, but to avoid any significant amendments that would dramatically change the balance of powers in Switzerland.

Federal Standards and Principles. Swiss Federalism has followed the tradition of all federal states in Europe, including the "executive federalism" of the European Union. These federal states provide as a major policy the implementation of federal law by the agencies of the member governments. There are usually no federal agencies dealing directly with the implementation of federal law. This is the responsibility of the cantons. Thus, all federal statutes and ordinances are in general first interpreted and applied by cantonal administrations and controlled by cantonal administrative courts, depending on cantonal administrative procedure. This type of federalism has been called "executive federalism" (Vollzugsfoderalismus). ${ }^{39}$ This very principle of executive federalism is for the first time now explicitly provided for in Article 46 of the new Constitution. Executive federalism is based on a hierarchical relationship between the cantons and the federal government in all matters of federal competencies.

${ }^{3 *}$ See also art. 42, par. 1, Constitution. For a thorough analysis of the distribution of powers see Blaise Knapp, "La répartition des compétences et la coopération de la Confédération et des cantons," Verfassungsrecht der Schweiz, eds. Aubert, Müller, and Thürer, pp. 457-472.

"Peter Saladin, "Rahmengesetzgebung im Bundesstaai," Die Kunst der l'erfassungserneuerung (Basle/ Frankfurt: Helbing \& Lichtenhahn, 1988), p. 189. 
Taking this context into account, the federal authorities are attempting to establish a new policy with regard to cantonal administration. They want to leave detailed regulations to the cantonal legislature and to restrict themselves to policymaking, to issuing federal standards and principles, and to empowering the cantons to implement those principles within their own legislation. Consequently, the competencies given to the Confederation in the Constitution have generally been restricted to legislative powers. Implementation of these statutes is part of the residual power of the cantons. This policy has not changed under the new Constitution. In fact, the cantons have had long experience in dealing directly with their citizens. If federal agents were to attempt to implement federal law in the cantons, the resistance of the population toward unknown federal agents coming from different ethnic communities would almost certainly arouse indignation.

\section{PARTICIPATION OF CANTONS IN THE DECISION-MAKING PROCESSES OF FEDERAL AUTHORITIES}

Self-rule and Shared Rule. According to the constitutions of 1848 and 1874, the autonomy of the cantons had clear priority. However, since 1874 , as a result of approximately 140 constitutional amendments, the originally extensive powers of the cantons have shifted slowly to the federal government. This process of centralization diminished cantonal autonomy gradually. As already mentioned, the new Constitution provides a general provision, which can be interpreted as a general clause like the principle of subsidiarity, but in this case diminishing cantonal autonomy by action of the federal legislative majority, as well as a more difficult procedure for constitutional amendments. A new constitutional amendment now also provides for federal competencies in the field of court procedural rules. This will have an important centralizing impact on the entire judiciary.

The challenge of the European Union will also have centralizing effects on Swiss federalism. This may have been the most important reason why the new Constitution focuses much more on the issues of shared rule than on self-rule. ${ }^{40}$ In this sense, Swiss federalism has been more and more influenced by the German tradition. Three major changes have to be mentioned in this context. The first two are obvious: the right of cantons to participate in the foreign policy decisions of the federal government and the general right to participate in internal federal legislation. Third, the general possibility for cantons to regulate matters of general concern through international or intercantonal treaties has to be mentioned. Partnership between cantons and between cantons and the federal government, as well as partnership with neighboring European regions, are probably the most interesting issues.

${ }^{40}$ See also Peter Hānni, Schweizerischer Föderalismus und europäische Integration (Zurich: Schulthess, 2000), pp. 388-389. 
Council of States and Executive Federalism. The strengthening of the shared rule principle has not led, as one might have expected, to a strengthening and widening of the powers of the second chamber. It has been implemented instead by strengthening the possibilities for cantonal executive bodies to participate in the decision-making processes of the federal government. In order to participate in the federal decision-making processes, cantonal executives have had to create a new body, which represents all the cantonal governments. Thus, the widening of the shared rule principle at the federal level has had as a direct consequence the establishment of the Council of Presidents of cantonal governments. ${ }^{41}$ This has led to better cooperation between cantonal governments as such. This development also has enabled the cantons to use new ways and tools for cantonal and intercantonal partnership cooperation. The creativity of this cooperative federalism is new, and may lead Switzerland to greater flexibility.

In the field of universities, the legislature has established a body composed of representatives of cantonal governments and of the federal council, whose task is to plan and establish strategies for developing federal and cantonal universities. With this new "superstructure" combining shared rule and self-rule in the field of higher education, Switzerland is trying to meet the new challenge of a "European Space of Higher Education" proclaimed in the Bologna-Declaration of 1999. There are also new tendencies that might even lead to supracantonal cooperation on regional bases of collaboration. This is already at least a partial reality in the field of professional education. There is discussion not only of direct partnership of executive bodies but also of cantonal parliaments. It may well be that this new flexibility of intercantonal cooperation will lead to the establishment of real intercantonal bodies with specific democratic legitimacy based on the citizens and united by a functional focus such as a school, hospital, or police region.

Thus, Swiss federalism will face new administrative bodies, new distinct regional parliaments, and new executive branches all united to fulfill specific tasks in order to have more efficiency. Federalism involving shared power in representative bodes will be supplemented by a shared power system of executive and administrative bodies. It seems clear, then, that the new Constitution does not restrict federalism only to the legislative branch and to representative bodies, but enlarges federalism to encompass the executive branches.

\section{PARTNERSHIP BETWEEN CONFEDERATION AND CANTONS}

Solidarity. Several years ago, the Canton of Basle introduced in its constitution a provision that imposed upon the cantonal authorities the responsibility to fight with all legal means proposals for any nuclear power plant that threatened to endanger the population of the canton. As cantonal

"See Kurt Nuspliger, "Grundzüge der Behōrdenstruktur im Verfassungsrecht der Kantone," V'erfassungsweht der Schweiz, eds. Aubert, Müller, and Thürer, pp. 1093-1094. 
constitutions have to be approved by the federal Parliament, the question arose as to whether such a cantonal constitutional provision, which may be contrary to the general interest of the Swiss population's dependence on atomic energy, would be acceptable. Parliament did approve the amendment with the argument that under the cantonal provision, authorities are only obliged to use legal and not illegal means in their struggle against nuclear power plants.

At almost the same time, Parliament had to approve the constitution of the Canton of Jura. This new canton provided in its constitution a provision to politically encourage the remaining Protestant but French-speaking neighboring minority of the Canton of Berne to secede from that canton and to join the new Canton of Jura. This article was considered a provision that would stir up secessionist conflict in the neighboring Canton of Berne. The federal Parliament did not approve the article, even though the provision did not extend to the new cantonal authorities of the Jura using illegal means.

The issue in both cases was solidarity. In the Basle case, it has been considered that solidarity was not violated. In the Jura case, the federal Parliament was of the opinion that the constitutional obligation to foster the secession of a region in a neighboring canton violates the principle of federal solidarity. The very issue with regard to solidarity is this: what solidarity can the majority reasonably and legitimately expect from the minorities, and what solidarity is necessary from the majority in order to have legitimacy with regard to the minorities?

A federation (foedus, alliance) can only exist on the basis of the solidarity of its partners. Partnership is indispensable not only between the cantons but also between the federal branches of government and cantonal branches of government. Without such solidarity, the Confederation cannot exist. This is the philosophy behind Article 44 of the new Constitution, which reads as follows:

1. The Confederation and the Cantons shall collaborate, and shall support each other in the fulfillment of their tasks.

2. They owe each other mutual consideration and support. They shall grant each other administrative and judicial assistance.

3. Disputes between Cantons, or between Cantons and the Confederation shall, to the extent possible, be resolved through negotiation or mediation.

In fact, federalism in such a small country as Switzerland is only possible if the division of powers finds its complementary balance in a network of informal cooperation at all levels of government and administration, including also labor unions and business, the so-called "social partners." This network might often not be very transparent because it is informal, 
but it is this comity of different partners that ultimately holds Switzerland together. The complexity of state tasks and state obligations requires such a cooperation not only among magistrates and elected authorities but also among civil servants of federal and cantonal administrations. This is the content of Article 44, par. $1 .{ }^{42}$

Although this provision was not part of the old formal tradition, its content was in fact the living reality. Without this reality, such a provision would remain only on paper. However, because it has been written on the basis of long-lasting political experience, it is only the formal and legal ratification of an attitude which is a historic reality.

The explicit obligation to solidarity is to be found in paragraph 2 of this article. This is not limited to an obligation of loyalty, as is the case according to the German constitution for the German Länder. It is an obligation to solidarity that goes beyond loyalty in the sense that it is less hierarchical and more driven by partnership. If partners, in particular those representing the majority, are not prepared to sacrifice some of their interests for the sake of the whole unity, federalism will sooner or later break into pieces. ${ }^{43}$

Supremacy of Federal Law. Not all federal states have clear provisions to guarantee the supremacy of federal law. ${ }^{44}$ The Swiss Constitution has since the beginning of the Confederation followed the American model of the supremacy clause. ${ }^{45}$ According to the European continental law systems, the "law" must be a unity in which different bills, statutes, and ordinances of federal, cantonal, and municipal governments are integrated in to a clear hierarchy. This is today apparent in the German constitution ${ }^{46}$ as well as for the European Union. ${ }^{47}$ Security of law, and in particular, equal protection can only be guaranteed on the basis of the principle of the supremacy clause.

In the old Constitution, the supremacy clause was hidden in the provisions regulating the transition. The new Constitution determines it clearly in Article 49: "Federal law takes precedence over contrary cantonal law. The Confederation shall ensure that the Cantons respect federal law." The Constitution thus implements Hans Kelsen's philosophy of the hierarchy of law. ${ }^{48}$

Constitutional Review and Rule of Law. Switzerland belongs to those states which had introduced constitutional review already in the nineteenth

${ }^{42}$ For the cooperative federalism, see Christian Dominicé, "Fédéralisme cooperatif," Zeitschrift für Schweizerisches Recht (1969): 743; Ulrich Hāfelin, "Der Kooperative Föderalismus in der Schweiz," Zeitschrif für Schweizerisches Recht (1969): 549; Peter Saladin, "Bund und Kantone," Zeitschrift für Schweizerisches Recht (1984): 590

${ }^{43}$ On the loyalty issue (Bundestreue), see Alfred Kölz, "Bundestreue als Verfassungsprinzip?" Schweizerisches Zentrablatl für Staats- und Verwaltungsrecht (1980): 145; Jaag, "Die Rechtsstellung der Kantone in der Bundesverfassung," pp. 482-483.

${ }^{44}$ This constitutional right is now explicitly provided in Article 49 par. 1 Constitution.

${ }^{45}$ See Article VI par. 2 of the US-Constitution.

${ }^{46}$ Article 31 German Fundamental Law.

${ }^{4}$ See European Court of Justice 1964, p. 1251-RS 6/64 (Costa/ENEL) esp. N 9-13.

${ }^{48}$ Hans Kelsen, General Theory of Norms (Oxford University Press, 1991), passim. See also Thomas Fleiner "Comparative Constitutional and Administrative Law," in: 75 Tul. L. Rev. 929 (2001): 932-933. 
century. This constitutional review, however, was limited to the review of cantonal statutes by the federal Court. It is true that at that time, the federal system could only function when citizens were able to defend their constitutional rights against the cantonal legislature before a federal court. ${ }^{49}$ Thus, the Constitution of 1848 provided a very limited possibility for the citizens to sue their canton before the federal Court and to defend their constitutional rights against violations by cantonal authorities. This constitutional protection was indispensable. The power to defend constitutional rights against cantonal authorities is also provided for in the new Constitution. ${ }^{50}$

However, although there have been many initiatives in Swiss history to introduce also the possibility of constitutional review of federal statutes, Parliament has ultimately rejected all those proposals. The majority of the Swiss are still too much committed to the idea of Jean Jacques Rousseau and his volonté générale, the notion that bills and statutes are not only written law but also the very implementation of justice, which cannot be nullified by a court. ${ }^{51}$ In their view, the legislature is the highest representative of the nation and therefore issues the volonté générale, which cannot be questioned for any constitutional reasons whatever. As all statutes passed by Parliament are subject to an optional referendum (Article 141), they are considered to be ratified either silently by the people, when they do not invoke the right of referendum, or explicitly because they have been approved in a referendum by the majority of the people.

Accordingly, there is no judicial body that would have the legitimacy to put into question what has been tacitly or explicitly ratified by the sovereign legislature. This argument has proved, even today, to be more convincing to the public against the traditional common-law argument that men should be governed by law and not by men. As a consequence, the cantons have no judicial channel to defend their autonomy against infringements by the federal legislature. Thus, constitutional review has remained a one-way road, providing protection against cantonal violations but not against violations by the federal legislature.

New Federal Responsibilities of the Confederation. Diversity and autonomy have been guaranteed up to now by the clear constitutional restriction of the federal powers. Direct democracy, the guarantee of cantonal autonomy in the Constitution, and a political climate defending federalism have been the real guarantees of Swiss multiculturalism. These instruments have been developed for the settlement of conflicts and for the defense of minority interests. The new Constitution includes specific obligations to care for, support, and sustain federalism, diversity, solidarity, and comity. ${ }^{52}$ The

${ }^{19}$ See Walter Kālin, "Verfassungsgerichtsbarkeit," Verfassungsrecht der Schweiz, eds. Aubert, Müller, and Thürer, pp. 1167-1181; Fleiner, "Cantonal and Federal Administration," François Dessemontet, Tugrul Ansay, Introduction to Swiss Law, 2nd ed. (The Hague: Kluwer/Schulthess, 1995), pp. 31-33.

${ }^{50}$ Article 189 par. 1 (a) Constitution.

"See Benjamin Barber, "How Swiss is Rousseau?" Political Theory 13 (1985): 485

${ }^{52}$ See Preamble, Article 2, 69, par. 3 and 71, par. 2 Constitution. 
federal government has to foster languages, to care for mutual understanding, to guarantee peace among religious communities, and to support poor regions, big cities, and mountain areas. The Confederation has, with regard to its legislation and administration, to take cantonal particularities into account and, at the same time, to provide the largest possible autonomy to the cantons (Article 46, par. 2). The Confederation has to respect cantonal independence and self-rule (Article 47), but it also has to decide at which moment some federal regulations need to be issued for the sake of uniformity (Article 42, par. 2).

Thus, the federal branches of government will have to assume new responsibilities. They will need new tools to provide information in order to plan and react according to their obligations. When they plan and decide upon new legislation or administrative measures, they are constitutionally obliged to make an assessment of the impact on federalism. However, they will determine the scope of federalism that is good for Switzerland, a responsibility they did not have to assume under the old Constitution.

\section{CONCLUSION}

Switzerland faces not only globalization, but also the fact that at the same time markets seem to have become both global and more local. Local nationalism, which one cannot calculate and foresee, is a challenge of even greater importance for a federal country composed of multiple diversity. Large and homogeneous nation-states are confronted with globalization. Multicultural federal states also face "localization." Thus, they are confronted with a double challenge. Globalization diminishes political capacities and, in particular, the power of states to react politically and to develop an independent political strategy within their territory. Emotional localization, on the other hand, can only be coped with if the political units display a high flexibility and the political capacity to find innovative answers to the requirements of national communities.

Internationalization, however, offers to units within federations an incredible opportunity to enlarge their political capacities and flexibility through regional international partnerships. In particular, one has to concede that for Switzerland through the European Union, the cooperation of cultural communities with their neighbor states will broaden and strengthen their self-consciousness toward the federal government. The growing international network between small communities will open new chances for partnership, cultural development, and cooperation. The federal government, in turn, is likely to be less confronted with emotional localization if the constitutional units through their international cooperation are able to feel more self-confident with regard to their opportunities for cultural partnership.

As for the shared rule, a federal order can only exist if there is at least a 
minimal consensus with regard to the basic values which the great bulk of society accepts throughout all its different cultural diversities. Therefore, cantonal constitutions must contain some basic shared values, which are generally accepted and thus approved by the federal Parliament. (Article 51, par 1).

If those shared values are not cultural, and in a multicultural society that cannot be the case, they must be political. If they are political, they ought to be universal and therefore acceptable for every human being. The Swiss values are certainly political, but one cannot claim that values such as direct democracy are universal. Thus, the basis of Swiss unity has to be found in political values that are widely accepted by the citizens of Swiss society. For any human being integrated in the Swiss tradition, these values are generally acceptable and inclusive; for people not familiar with the democratic tradition of the cantons and the Confederation, they are exclusive. Thus, based on political values such as federalism and direct democracy, a specific political culture has been established that seems to hold the fragmented nation together.

Those who consider federalism as a basic value for a polity have to be aware that federalism in history has been one of the most dynamic and flexible but also fragile structures for state order. Contrary to unitary systems, federalism can by formed and developed in great diversity. Shared rule and self-rule can be strengthened, broadened, weakened, or restricted. Even the principle of equal rights of federal subjects is not taboo. There are important examples of asymmetric federal states. ${ }^{53}$ It is the existing diversity of the society, its traditions, cultures and languages, and political values (consumer democracy or citizen democracy) that determine the concrete shape of a federal polity. Those pre-constitutional realities are the decisive factors that influence a federal system and create or destroy its legitimacy. This inherent openness and dynamism should enable federal systems to join international organizations and to delegate part of their already limited and divided sovereignty much better than inflexible unitary states. Thus, federal systems should more easily adapt to the modern trends of internationalization, European integration, and globalization.

For Switzerland, the very challenge will be whether it can transcend its philosophy and its system of a multicultural society composed of traditional communities to evolve into a system that is open not only to global capital but also to global labor. Can federalism become a tool to integrate different cultures immigrating into Switzerland? As in most European states, Switzerland is also threatened by racism, which discriminates against foreigners. Will it be able to face this challenge based on the tradition of diversity and federalism?

${ }^{53}$ See Ronald Watts, "The Theoretical and Practical Implications of Asymmetrical Federalism," Accommodating Diversity: Asymmetry in Federal Siates, ed. Robert Agranoff (Baden-Baden: Nomos, 1999), p. 24. 
